\begin{abstract}
Citation: Yayla, Ö., \& Kendir, H., \& Arslan, E., Moderator Role of Gender in the Effect of Environmental Commitment on Environmental Responsibility Behaviour in Hotel Employees, BMIJ, (2020), 8(5): 3971-3990 doi: http://dx.doi.org/10.15295/bmij.v8i5.1626
\end{abstract}

\title{
MODERATOR ROLE OF GENDER IN THE EFFECT OF ENVIRONMENTAL COMMITMENT ON ENVIRONMENTAL RESPONSIBILITY BEHAVIOUR IN HOTEL EMPLOYEES
}

Özgür YAYLA ${ }^{1}$

Hakan KENDİR 2

Emin ARSLAN 3

\author{
Received Date (Başvuru Tarihi): \\ $18 / 09 / 2020$ \\ Accepted Date (Kabul Tarihi): \\ $19 / 11 / 2020$ \\ Published Date (Yayın Tarihi): \\ $25 / 12 / 2020$
}

In the article, the first author is in the role of Corresponding Author.

ABSTRACT

Keywords:

Environmental Commitment,

Environmental Responsibility Behaviour,

Hotel Employees,

Antalya

JEL Codes:

L83, Q56
The primary purpose of the present study is to demonstrate the moderator role of gender in the effect of the environmental commitment of hotel business employees on environmental responsibility behaviour. The Scanning Method was applied in the study. The sampling of the study consisted of 397 employees working in five-star hotel businesses in the Antalya region between September and October 2019. The Questionnaire form was preferred as the data collection tool in the study. The data obtained as a result of the study were subjected to statistical analyses. These analyses were frequency analysis, reliability analysis, factor analysis, and regression analysis. As a result of the regression analysis, it was found that the environmental commitment levels of employees in hotel businesses had a positive and moderate effect on environmental responsibility behaviour. It was also found that gender had a moderator role in the effect of environmental commitment in employees on environmental responsibility behaviour.

\section{OTEL ÇALIŞANLARINDA ÇEVRESEL BAĞLILIĞIN ÇEVRESEL SORUMLULUK DAVRANIŞINA ETKISIINDE CINSIYYETINN MODERATÖR ROLÜ}

$\ddot{O} Z$

\section{Anahtar Kelimeler:}

Çevresel Bă̆lılık,

Çevresel Sorumluluk Davranışı,

Otel Çalışanları,

Antalya

JEL Kodlarn:

L83, Q56
Bu araştırmanın temel amacl, otel işletmelerindeki çalışanlarda çevresel bağhliğın çevresel sorumluluk davranışına etkisinde cinsiyetin moderatör rolünü ortaya koymaktır. Araştırmada tarama yöntemi uygulanmıştır. Araştırmanın örneklemini 2019 yılı EylülEkim ayları arasında Antalya bölgesinde bulunan beş yıldızlı otel işletmelerindeki 397 çalışan oluşturmaktadır. Araştırmada veri toplama yöntemi olarak anket tekniği tercih edilmiştir. Araştırma sonucu elde edilen veriler istatistiksel analizlere tabi tutulmuştur. Bu analizler frekans dă̆ılımı, güvenilirlik analizi, faktör analizi ve regresyon analizidir. Regresyon analizi sonucunda, otel işletmelerinde çalışanların çevresel băglılık düzeylerinin çevresel sorumluluk davranışı üzerinde pozitif yönlü orta derecede bir etkisinin olduğu saptanmıştır. Ayrıca çalışanlarda çevresel bağhlĭğın çevresel sorumluluk davranışına etkisinde cinsiyetin moderatör role sahip olduğu tespit edilmiştir.

\footnotetext{
${ }^{1}$ Asst. Prof. Dr., Akdeniz Unv., Manavgat Tourism Faculty, ozguryayla@akdeniz.edu.tr, https://orcid.org/0000-0001-7124-9311

2 Asst. Prof. Dr., Tokat Gaziosmanpaşa University, Zile Dinçerler Tourism and Hotel Management College, hakan.kendir@gop.edu.tr,

3 Asst. Prof Dr, Tokat Gaziosmanpaşa Univesity, emin.arslan@gop.edu.tr, https:// orcid.org/0000-0002-1356-1339 https://orcid.org/0000-0003-1592-8162
} 


\section{INTRODUCTION}

Environmental problems and environmental protection are among the most focused issues in the entire world. Considering this fact, environmental problems, which constitute a compassionate issue in tourism, force tourism organizations and businesses to take precautions. As a reaction to environmental problems in recent years, the hospitality sector has started to apply for various environmental programs. The purpose of the environmental programs of hotels is based on reasons such as developing an environmentally friendly image for customers, protecting the environment, and for cost-saving purposes. For this reason, many hotel businesses prefer to have and use different eco-label certificates, whose number is more than 50 worldwide (Chan, 2013). Environmental applications like "Green Star" certificate given to hotels in Turkey have become common in recent years. In this respect, as of 2020, the number of hotels with "Green Star" certificates reached 478 (KTB, 2020). A green and environmental image is an effective way of attracting customers to hotels. However, these environmental practices have also some financial costs. Therefore, businesses have to consider environmental responsibility and financial performance (Mercado \& Walker, 2012). Right at this point, sensitivities like environmental responsibility behaviour and environmental commitment are useful for hotel businesses.

Studies conducted on environmental responsibility behaviour and environmental commitment focus on the behaviour of tourists and hotel guests (Lee \& Jan, 2015; Cheng \& Wu, 2014; Chiu et al., 2014; Han \& Yoon, 2015; Su \& Swanson, 2017; Han et al., 2019). However, there are studies in the literature associating the concept of environmental responsibility with the commitment concept (Lee, 2011; He et al., 2018). In this respect, it was noted that these studies focused mostly on tourists. However, it is known that hotel enterprises cause some environmental problems (unplanned urbanization, waste problem, agricultural land occupation, high energy and water consumption) in practice. Many of these problems arise from the inadequate sensitivity and knowledge of hotel employees about the environment. Despite this problem, there are no adequate studies in the tourism literature on the environmental attitudes and perceptions of hotel employees, which are among the essential 
components of hotel enterprises. Employees of businesses that want to have the image of being a "Green Hotel" must also show environmentalist behaviours. That is why this situation should be investigated academically. Based on this, the present study has aimed to measure the environmental commitment levels and environmental responsibility behaviours of hotel employees and to determine the role of gender in the relation between these two variables.

\section{LITERATURE REVIEW}

\subsection{Environmental Commitment}

Environmentalism, which supports and encourages the protection of natural resources and the transfer of these to future generations, stands out as an important concept that has been discussed in recent years with the use of disposable products too much, environmentally damaging manufacturing processes, and due to the disruption caused by environmental disasters (Easterling, Kenworthy \& Nemzoff, 1996; Han, Hsu \& Sheu, 2010). The interaction between the individual and the natural environment, which is an indispensable element of human life, and which is frequently associated with each other, has caused that the concept of environmental commitment emerged (Davis, Le \& Coy, 2011). Environmental commitment is based on the "Commitment Model" of Rusbult (1980), which was derived from the theory of Mutual Commitment Theory that was developed by Kelley and Thibaut (1978) (Coy et al., 2013). In the relevant theory, "commitment" is defined as a subjective trust experience, which the individual shows in terms of his/her needs. In other words, individuals are more committed to meeting their needs than they depend on anything else. The individual's commitment to the natural environment to sustain his/her life may be given as an example of this (He et al., 2018). The environmental commitment concept is defined as the long-term adaptation and psychological attachment to the natural environment (Davis, Le \& Coy, 2011).

The Mutual Commitment Theory focuses on how a relation structure like human-natural environment affects motivation and behaviour in time (Kelley \& Thibaut, 1978). The Natural Environmental Management, which emerged as a result of the pressures of individuals with high environmental commitment and the 
regulations made by the administrations of countries, has become one of the most critical issues of businesses. These issues significantly affect all processes of the activities of a business (Henriques \& Sadorsky, 1999). Especially the rapid change in desires and expectations with postmodernism has led to increased production followed by rapid consumption, which, in turn, fueled the depletion of natural resources and environmental destruction. On the other hand, individuals who realize that protecting natural resources is vital in terms of sustainability of life prefer the goods and services produced by environmentally sensitive enterprises (Rahman \& Reynolds, 2016).

The environmental management system of the businesses that produce goods and services will ensure that employees are environmentally sensitive (Perez-Lopez, Moreno-Romero \& Barkemeyer, 2015), making it easier for consumers who prefer ecofriendly products are directed to these businesses, becoming loyal consumers (Han, Lee \& Kim, 2018). Hotel businesses, which produce services and have an essential share in the tourism sector, are known as Green Hotels thanks to the environmentally friendly applications they have implemented in recent years (Han \& Yoon, 2015). Also, an environmentally conscious hotel business implements its green management/marketing strategies actively and follows environmentally-friendly guidelines developing environmentally friendly practices to limit the damage given to the environment (Han, 2015). Environmentally friendly implementations that are developed by hotels attract tourists who are committed to the environment. On the other hand, these practices also enable hotel employees to change their opinions on the environment, causing more environmentally sensitive and responsible behaviours (Molina-Azorin et al., 2009).

\subsection{Environmental Responsibility Behaviour}

The environmental problems, which emerged as a result of industrialization, rapid population growth, and urbanization, have led to many negativities like climate change, global warming, extinction of species, and destruction of natural areas (Uzzell, 2000; Ambec \& Lanoie, 2008; Mercado \& Walker, 2012). Natural beauties are among the most critical assets of destinations for the tourism sector. Also, the natural 
environment is one of the factors attracting most tourists to a particular destination. When the literature was reviewed, it was seen that studies on the environment in the field of tourism focused on sustainable development and touristic consumer preferences. The developments, especially in the tourism sector, has been an essential topic of discussion as well as bringing with it the economic development and the damage to the natural environment (Kasim, 2006; Cheng \& Wu, 2014; Chiu et al., 2014; Han \& Yoon, 2015; Su \& Swanson, 2017; He et al., 2018).

On the other hand, the intense tourist mobility in destinations and unplanned tourism investments are also the cause of environmental problems like unplanned urbanization, air/water pollution, and greenhouse gas emissions (Razaa et al., 2017). Based on this point, environmental problems emerging as a result of tourism development raised the environmental responsibility concept. In the tourism literature, the environmental responsibility concept is discussed in different aspects. Table 1 shows essential studies in which the environmental responsibility concept was examined in the tourism literature. 
Table 1. Primary Studies Conducted on Environmental Responsibility in The Field of Tourism

\begin{tabular}{|c|c|c|c|c|}
\hline Authors & Conducted in & Type & Sampling & Findings \\
\hline $\begin{array}{l}\text { Kasim, } \\
2006\end{array}$ & Worldwide & Qualitative & - & $\begin{array}{l}\text { It was emphasized that the damage caused by } \\
\text { tourism activities to the environment had } \\
\text { been increasing day by day. In terms of } \\
\text { sustainability, it was recommended to all } \\
\text { stakeholders in tourism to prioritize issues } \\
\text { that required environmental responsibility. } \\
\text { The researcher especially stated that hotel } \\
\text { businesses should fulfil their environmental } \\
\text { obligations. }\end{array}$ \\
\hline $\begin{array}{l}\text { Cheng \& } \\
\text { Wu } \\
(2014)\end{array}$ & $\begin{array}{c}\text { Penghu Island - } \\
\text { Taiwan }\end{array}$ & Quantitative & & $\begin{array}{l}\text { It was found that environmental knowledge } \\
\text { level and environmental sensitivity were } \\
\text { associated with environmental responsibility } \\
\text { behaviour. It was also revealed that } \\
\text { environmental sensitivity and destination } \\
\text { loyalty mediated the relation between } \\
\text { environmental knowledge and environmental } \\
\text { responsibility. }\end{array}$ \\
\hline $\begin{array}{l}\text { Chiu et } \\
\text { al., } 2014\end{array}$ & $\begin{array}{c}\text { Taijiang } \\
\text { National Par } \\
\text { Taiwan }\end{array}$ & & $\begin{array}{l}328 \\
\text { urists }\end{array}$ & $\begin{array}{l}\text { It was determined that after the participation } \\
\text { of tourists in ecotourism activities, the value } \\
\text { they perceived in the destination and } \\
\text { satisfaction from the destination affected the } \\
\text { environmental responsibility behaviour level. }\end{array}$ \\
\hline $\begin{array}{l}\text { Han \& } \\
\text { Yoon, } \\
2015\end{array}$ & The U. & itative & $\begin{array}{l}384 \text { hotel } \\
\text { guests }\end{array}$ & $\begin{array}{l}\text { It was concluded that environmental } \\
\text { responsibility behaviour has an impact on } \\
\text { individuals on their decisions to choose eco- } \\
\text { friendly hotels. }\end{array}$ \\
\hline $\begin{array}{c}\text { Su \& } \\
\text { Swanson, } \\
2017\end{array}$ & Hunan - China & Quantitative & $\begin{array}{l}539 \\
\text { Chinese } \\
\text { tourists }\end{array}$ & $\begin{array}{l}\text { It was determined that the touristic } \\
\text { consumption feelings and destination } \\
\text { definitions of visitors had a mediator effect in } \\
\text { the relation between the perception of social } \\
\text { responsibility of the destination and the } \\
\text { environmental responsibility behaviours of } \\
\text { tourists. }\end{array}$ \\
\hline
\end{tabular}




\begin{tabular}{|c|c|c|c|c|}
\hline Authors & Conducted in & Type & Sampling & Findings \\
\hline $\begin{array}{l}\text { He et al., } \\
2018\end{array}$ & $\begin{array}{l}\text { Yuelu Mountain } \\
\text { - China }\end{array}$ & Quantitative & $\begin{array}{c}568 \\
\text { visitors }\end{array}$ & $\begin{array}{l}\text { It was determined that tourist satisfaction and } \\
\text { environmental commitment played a full } \\
\text { mediator role between environmental } \\
\text { responsibility behaviour and perceived value } \\
\text { from visiting a destination. It was also } \\
\text { determined that the quality of } \\
\text { environmentally sensitive employees affected } \\
\text { the satisfaction of tourists in showing } \\
\text { environmental responsibility behaviour. }\end{array}$ \\
\hline $\begin{array}{l}\text { Han et } \\
\text { al., } 2019\end{array}$ & $\begin{array}{l}\text { US Airplanes - } \\
\text { USA }\end{array}$ & Quantitative & $\begin{array}{l}309 \text { airway } \\
\text { passengers }\end{array}$ & $\begin{array}{l}\text { It was found that environmental } \\
\text { responsibility and intent perceptions for the } \\
\text { planes for customers using airlines had effects } \\
\text { in terms of gender and age. It was also stated } \\
\text { that gender had a moderator effect. }\end{array}$ \\
\hline
\end{tabular}

A total of 7 of the primary studies in the tourism literature, which are about environmental responsibility behaviour, are presented in Table 1 above. In this respect, it may be argued that the studies mainly discussed the sampling of tourists and customers. On the other hand, an exciting issue in one of the studies (He et al., 2018) is that businesses with employees who care about the environment should be cared and recommended by visitors. For this reason, examining environmental commitment and environmental responsibility behaviour will make a significant contribution in terms of literature not only in terms of tourists but also in hotel business employees. The following hypothesis was developed in this respect.

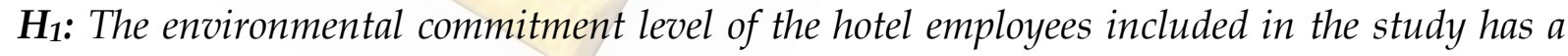
positive effect on environmental responsibility behaviour.

Another interesting issue in one of the studies given in Table 1, (Han et al., 2019) and in different studies outside the tourism field not presented in the table (Sakellari \& Skanavis, 2013; Xiao \& Hong, 2018), is the result that demographic variables like gender and age affect environmental perceptions and attitudes. In this respect, environmental responsibility behaviour and environmental commitment level in hotel 
employees may vary according to the demographic structure. For this reason, based on these explanations, the following hypothesis was developed.

$\mathrm{H}_{2}$ : Gender has a moderator role in the relationship between environmental commitment levels and environmental responsibility behaviours of hotel employees participating in the study.

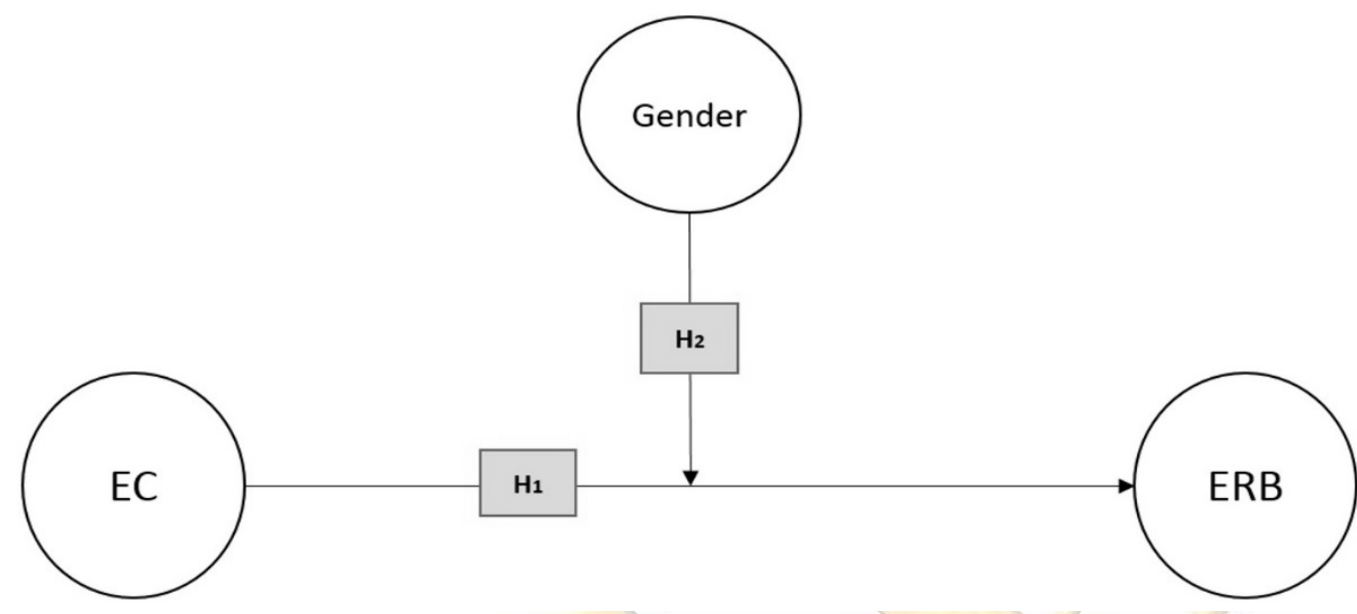

Figure 1. Research Model

The research model is seen in Figure 1 above. Among the abbreviations given in the model, EC refers to Environmental Commitment, and ERB refers to Environmentally Responsible Behaviour.

\section{METHODOLOGY}

The Scanning Method, which is among the descriptive study models, was preferred in the study, and the Quantitative Method was used. Since it was not possible to determine the total study population as an exact number, the convenience sampling of non-probability sampling methods was used. According to Hair et al. (2014), for the Explanatory Factor Analysis, it is necessary to reach ten times more participants than the number of the statements presented in the research scales. The environmental commitment and environmental responsibility behaviour scales consisted of a total of 10 expressions. Therefore, at least 100 people should be reached. In this study, the study population consisted of the five-star hotel employees in Antalya. Depending on the purpose of the study, the data were collected in September and October 2019. For this reason, it was not necessary to obtain the ethics committee certificate required by ULAKBIM TRDIZIN for the researches that have been done 
since the beginning of 2020. Hotel businesses which have environmental sensitivity and are among the most critical components of the tourism sector were chosen in line with the purpose of the research. In this context, the data of the research were collected from employees working in hotel businesses in the September-October period, 2019. More than 50 employees were included in the pilot study in the first step. As a result of the pilot study, it was concluded that the scales in the questionnaire were suitable, and the ultimate data were collected in the second step. A total of 450 questionnaire forms were distributed, incomplete and incorrect forms were eliminated from the study, and analyses were made with 397 questionnaires.

The questionnaire form of the study consisted of three parts. In the first part, there were expressions aimed to determine the demographic characteristics of the employees. In the second part, the Environmental Commitment Scale, which was developed by Davis et al. (2009) to measure the environmental commitment of hotel staff, and which was used by He et al. (2018), consisting of 4 expressions and one dimension, was preferred. In the third part of the study, the scale that was developed and used by Cheng et al. (2013), Chiu et al. (2014), and He et al. (2018) to measure environmental responsibility behaviour was preferred. This scale consisted of 6 expressions and one dimension. The expressions in both scales were rated in 5-Point Likert style and were presented to hotel employees.

Depending on the purpose of the study, the data were transferred to the SPSS 20 Package Program, and the percentage and frequency tables were used. Normality test was used to check whether the data are parametric or not. In this context, the kurtosis and skewness values of all the expressions in the scales were between +1.5 and -1.5, and it was determined that the data were distributed normally (Kline, 2011). As a result, the Simple Linear Regression Analysis was used to determine the effect of environmental commitment on environmental responsibility behaviour. The SPSS Process Macro Program was also used to determine the moderator role of gender in this effect. 


\section{FINDINGS}

The findings of the study have been presented in this section. In this respect, frequency analysis, factor analysis, and regression analysis results are given respectively. The demographic characteristics of the hotel employees who participated in the questionnaire application that was conducted in the scope of the study are given in Table 2.

Table 2. Demographic Characteristics of Participants

\begin{tabular}{|c|c|c|c|}
\hline & Demographic Variables & $\mathbf{n}$ & $\%$ \\
\hline \multirow{2}{*}{ Gender } & Male & 243 & 61,2 \\
\hline & Female & 154 & 38,8 \\
\hline \multirow{5}{*}{ Age } & $18-25$ years & 100 & 25,2 \\
\hline & $26-33$ years & 218 & 54,9 \\
\hline & $34-41$ years & 51 & 12,8 \\
\hline & $42-49$ years & 13 & 3,3 \\
\hline & 50 years and older & 15 & 3,8 \\
\hline \multirow{2}{*}{$\begin{array}{c}\text { Marital } \\
\text { Status }\end{array}$} & Married & 172 & 43,3 \\
\hline & Single & 255 & 56,7 \\
\hline \multirow{5}{*}{$\begin{array}{c}\text { Education } \\
\text { Status }\end{array}$} & Primary & 24 & 6,0 \\
\hline & Secondary & 143 & 36,0 \\
\hline & Vocational School & 77 & 19,4 \\
\hline & Undergraduate & 141 & 35,5 \\
\hline & Postgraduate & 12 & 3,0 \\
\hline \multirow{3}{*}{$\begin{array}{c}\text { Sectoral } \\
\text { Experience }\end{array}$} & Less than 1 year & 12 & 3,0 \\
\hline & 1-10 years & 242 & 61,0 \\
\hline & More than 11 years & 143 & 36,0 \\
\hline
\end{tabular}

When Table 2 is examined, it is seen that $61.2 \%$ of the employees are male, and $38.8 \%$ are female. The age groups are as follows; $25.2 \%$ are between $18-25,54.9 \%$ are between $26-33,12.8 \%$ are between $34-41,3.3 \%$ are between $42-49$, and $3.8 \%$ are aged 50 and over. A total of $56.7 \%$ of the employees who have filled out the questionnaires are single. Besides, $6 \%$ had primary education, $36 \%$ had secondary education, $19.4 \%$ had an associate degree, $35.5 \%$ had undergraduate degrees, and 3\% had postgraduate education. When the distribution for sectoral experiences is examined, it can be understood that 3\% has less than 1-year experience, $61 \%$ has worked in the sector for 1-10 years, and $36 \%$ has worked for 11 years or more. 
Table 3. Factor Analysis Results of Environmental Commitment Scale

\begin{tabular}{l}
\hline \multicolumn{1}{c}{ EXPRESSIONS } \\
\hline Environmental Commitment \\
\hline I am determined in considering the interests of the environment at the \\
hotel I am staying. \\
\hline I think that I will deal with environmental activities more in the future. \\
\hline I am quite committed to the natural environment of the business I work \\
for. \\
\hline I am committed to the natural environment of the hotel and its \\
surroundings with strong ties. \\
\hline Total Scale Reliability and Variance
\end{tabular}

The results of the factor analysis and reliability analysis for the Environmental Commitment Scale used in the study are given in Table 3. When the findings in the table have been examined, in order to determine the analysis adequacy of the sampling number that is related to the scale, the KMO value has been checked, and it is 0.731 . The results show that the KMO value is higher than 0.6 and that the Bartlett Test is significant (Hair et al., 2014), which shows that the data have been suitable for factor analysis. It has also been determined that the Environmental Commitment Scale explains approximately $61 \%$ of the total variance.

The factor loading values of the scale items being 0.50 or above is considered as a criterion. Factor loadings are at the lowest level as 0.709 in the descriptive factor analysis. Also, the Cronbach's Alpha (CA) value has been calculated to determine the internal consistency and reliability of the scale and is 0.787 . It can be understood that this is above the generally accepted minimum value (Hair et al., 2014). As a result, it can be argued that the environmental commitment scale is reliable. 
Table 4. Factor Analysis Results of the Environmental Responsibility Behaviour Scale

\begin{tabular}{l}
\hline \multicolumn{1}{c}{ EXPRESSIONS } \\
\hline Environmental Responsibility Behaviour \\
\hline I obey the environmental protection rules defined by the hotel. \\
\hline I prevent the organizations and activities that may harm the environment. \\
\hline I clean up the garbage and wastes during my shift. \\
\hline I continuously follow the legal regulations regarding the environment. \\
\hline When I see garbage or wastes on the ground, I take them and put them in \\
the litter bin. \\
\hline I try to correct the behaviours of others regarding the protection of the \\
environment.
\end{tabular}

The factor analysis and reliability analysis results of the Environmental Responsibility Behaviour Scale used in the study have been presented in Table 4 . When the findings in the table have been examined, in order to determine the analysis adequacy of the sampling number that is related to the scale, the KMO value has been checked, and it is 0.697 . The results show that the KMO value is higher than 0.6 and that the Bartlett Test result was significant (Hair et al., 2014), which shows that the data were suitable for factor analysis. Also, it has been found that the Environmental Responsibility Behaviour Scale explained approximately $60 \%$ of the total variance.

As a result of the descriptive factor analysis, the factor loadings are the lowest at 0.541. Also, the Cronbach's Alpha (CA) value was examined to determine the internal consistency reliability of the scale and has been calculated as 0.718 . It can be understood that this was above the generally accepted minimum value (Hair et al., 2014). As a result, the environmental responsibility behaviour scale is reliable. 
Table 5. Effect of EC on ERB

\begin{tabular}{|c|c|c|c|c|c|c|c|}
\hline \multirow{2}{*}{$\begin{array}{l}\text { Independent } \\
\text { variables }\end{array}$} & \multicolumn{2}{|c|}{$\begin{array}{c}\text { Unstandardized } \\
\text { Coefficients }\end{array}$} & \multirow{2}{*}{$\begin{array}{c}\begin{array}{c}\text { Standardized } \\
\text { Coefficients }\end{array} \\
\text { Beta }\end{array}$} & \multirow[b]{2}{*}{$\mathbf{t}$} & \multirow[b]{2}{*}{ Sig. } & \multirow[b]{2}{*}{$\mathbf{F}$} & \multirow[b]{2}{*}{$\mathbf{R}^{2}$} \\
\hline & Beta & S.D. & & & & & \\
\hline Constant & 2,053 & 0,43 & - & 13,106 & $0,000^{*}$ & \multirow{2}{*}{192,937} & \multirow{2}{*}{0,326} \\
\hline EC & 0.515 & 0,47 & $0,573^{*}$ & 13,890 & $0,000^{*}$ & & \\
\hline
\end{tabular}

In Table 5, according to the results of the Simple Linear Regression Analysis made to determine the effect of environmental commitment on environmental responsibility behaviour, environmental commitment is the independent variable, and environmental responsibility behaviour is the dependent variable. It has been found that the linear regression model between the variables is significant in the analysis results $(\mathrm{F}=192.937 ; \mathrm{p}<0.001)$. When the model is examined, it has been found that oneunit increase in environmental commitment makes a positive change of 0.573 unit in environmental responsibility behaviour. For this reason, the " $\mathbf{H}_{1}$ : Environmental commitment levels of hotel employees participating in the study have a positive effect on environmental responsibility behaviour" has been accepted.

Table 6. Regression Analysis Results Showing Moderator Effect

\begin{tabular}{lcccc}
\hline Variables & $\boldsymbol{\beta}$ & CI & Standard Error & t \\
\hline Constant & $0,877^{*}$ & {$[0,05,1,81]$} & 0,474 & 1,98 \\
\hline EC $(\mathrm{X})$ & $0,706^{* *}$ & {$[0,53,0,98]$} & 0,113 & 6,73 \\
\hline Gender $(\mathrm{W})$ & $0,869^{*}$ & {$[0,24,1,49]$} & 0,315 & 2,75 \\
\hline X.W & $0,181^{*}$ & {$[0,32,0,51]$} & 0,074 & 2,43 \\
\hline & $\mathrm{R}=0,59, \mathrm{R}^{2}=0,35,{ }^{*} \mathrm{p}<0,05{ }^{* *} \mathrm{p}<0,001 ;$ EC: Environmental Commitment & & \\
\hline
\end{tabular}

The Regression Analysis results based on the Bootstrapping Method to test the moderator role of gender on the effect of the environmental commitment of hotel employees on environmental responsibility behaviour have been presented in Table 6 . It is argued that the Bootstrapping Method produces more reliable results than the traditional method of Baron and Kenny (1986) (Hayes, 2013). The analyses were made 
by using the Process Macro that was developed by Hayes (2013). The 5000-re-sampling option was preferred in the analysis with the Bootstrapping Method. In the moderator effect analysis made with the Bootstrapping Method, it is required that the values in the $95 \%$ Confidence Interval obtained as a result of the analysis should not cover the "zero" value to support the study hypothesis. The regression analysis results are given in the table. According to the results, it can be seen that all predictive variables included in the regression analysis explain 35\% of the change in environmental responsibility behaviour. Also, gender affects environmental responsibility behaviour $(\beta=0.869, \mathrm{p}<0.05)$. It has been found that the moderator effect of environmental commitment and gender variables on environmental responsibility behaviour is significant $(\beta=0.181, \mathrm{p}<0.05)$. According to this result, the hypothesis " $\mathbf{H}_{2}$ : Gender has a moderator role in the relation between the environmental commitment levels of hotel employees participating in the study and environmental responsibility behaviours" has been accepted.

Table 7. Moderator Effect Results of Gender Variable

\begin{tabular}{lccccc}
\hline Gender & $\boldsymbol{\beta}$ & $\mathbf{C I}$ & Standard Error & $\mathbf{T}$ & $\mathbf{p}$ \\
\hline Male & 0,579 & {$[0,48,0,67]$} & 0,04 & 11,80 & $0,000^{*}$ \\
\hline Female & 0,398 & {$[0,29,0,51]$} & 0,05 & 7,13 & $0,000^{*}$ \\
\hline
\end{tabular}

In Table 7, two different regression statistics on whether the effect of environmental commitment on environmental responsibility behaviour is significant in case gender, which is the moderator variable, is male (0.579) and female (0.398). According to the regression results, the effect of environmental commitment is significant on environmental responsibility behaviour in males, and this effect is approximately $58 \%$. However, this effect in women is significant, and the level of the effect was approximately $40 \%$. 


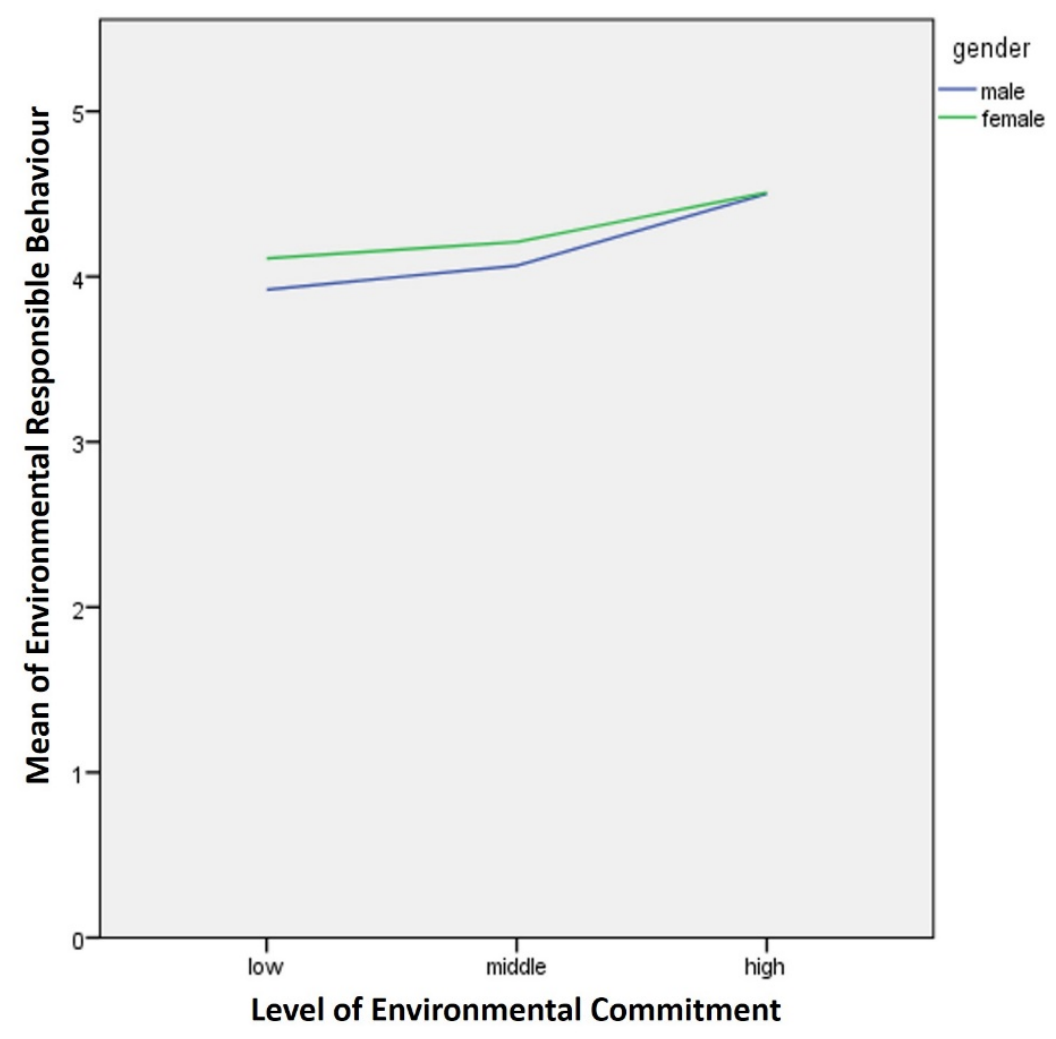

Figure 2. Graphical Notation of the Moderator Effect of Gender

According to the analysis, a one-unit increase in environmental commitment provided a $58 \%$ increase in environmental responsibility behaviour in men and $40 \%$ in women. The graphic of this effect is shown in Figure 2. When the figure is examined, it is observed that environmental responsibility behaviour also increases in cases where environmental dependence is high in men and women.

\section{RESULT AND RECOMMENDATIONS}

The sampling of this study, which aimed to measure the environmental commitment levels and environmental responsibility behaviours of employees in hotel enterprises, and to determine the role of gender in the relation between these two variables, consisted of 397 staff working in five-star hotel businesses in Antalya. A total of $61.2 \%$ of the hotel employees who made up this sampling were male, and $38.8 \%$ were female. The rate of females working in the tourism sector in Turkey was projected to be around $27.3 \%$ and will be $36.5 \%$ by 2023 (WTTC, 2014). Considering these data, the $38.8 \%$ female employee rate detected in this study is in line with the current situation in tourism employment. 
According to the results of the regression analysis made in the scope of the present study, the environmental commitment levels of hotel employees participating in the study positively affect environmental responsibility behaviour. This result is similar to the results of other studies conducted on tourists in the literature (Lee, 2011; He et al., 2018). In this respect, hotel employees who have high environmental commitment levels are expected to behave positively in terms of environmental responsibility. Based on this, hotel businesses that wish to show an environmentalist image should inform their staff about environmental sensitivity, and give them environmental awareness. In this context, not only the hotel businesses but also NGOs and trade unions that operate in the hotel management business field also have important tasks. Therefore, it will be possible to minimize destruction to the environment as the data will be transmitted to hotel business employees.

Another result obtained in the present study was that female employees had higher scores compared to men in terms of environmental commitment and environmental responsibility behaviours among hotel employees. In other words, the environmental sensitivity of female employees was higher than men. This result is similar to the qualitative studies in the literature (Sakellari \& Skanavis, 2013; Chan, 2013; Han et al., 2019; Xiao \& Hong, 2018). On the other hand, the relation detected between the environmental commitment level and environmental responsibility behaviours was the most distinctive finding that made the present study necessary. As a result of the analyses, the environmental commitment level in male employees was found to affect the development of environmental responsibility behaviour further. In this respect, as the level of environmental commitment of male employees increased, the tendency to show environmental responsibility behaviour positively increased more compared to females. For this reason, hotel businesses, NGOs and educational institutions related to hotel businesses should provide more information about the environment, especially to male employees, and increase their environmental commitment and awareness.

The present study had some limitations. It is a limitation of the study that it was conducted in certain months in 2019. On the other hand, it is another limitation that it covered only the hotel personnel in Antalya. For this reason, it might be suggested that 
future studies are conducted in the field of hotel businesses at different times and to include different regions. It can also be recommended to conduct a similar study by adding different variables to those included in this study. Academicians in the field of tourism can consider these issues in future studies. As a result, all stakeholders operating in the field of hotel businesses can benefit from the findings and recommendations obtained in the scope of this study. 


\section{REFERENCES}

Ambec, S. \& Lanoie, P. (2008). Does it pay to be green? A systematic overview. Academy of Management Executive. 22(4): 45-56. DOI: 10.5465/amp.2008.35590353.

Baron, R.M. \& Kenny, D.A. (1986). The moderator-mediator variable distinction in social psychological research: conceptual, strategic, and statistical considerations. Journal of Personality and Social Psychology.

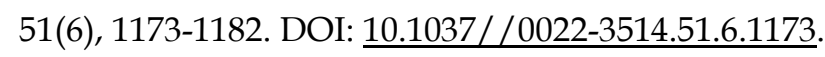

Chan, E.S.W. (2013). Gap analysis of green hotel marketing. International Journal of Contemporary Hospitality Management. 25(7). 1017-1048. DOI: 10.1108/IJCHM-09-2012-0156.

Cheng, T.-M., Wu, H. C., \& Huang, L.-M. (2013). The influence of place attachment on the relationship between destination attractiveness and environmentally responsible behaviour for island tourism in Penghu, Taiwan. Journal of Sustainable Tourism. 21(8): 1166-1187. DOI: 10.1080/09669582.2012.750329.

Cheng, T.-M., \& Wu, H.C. (2014). How do environmental knowledge, environmental sensitivity, and place attachment affect environmentally responsible behaviour? An integrated approach for sustainable island tourism. Journal of Sustainable Tourism. 23(4): 1-20. DOI: 10.1080/09669582.2014.965177.

Chiu, Y.-T. H., Lee, W.-I., \& Chen, T.-H. (2014). Environmentally responsible behaviour in ecotourism: Antecedents and implications. Tourism Management. 40: 321-329. DOI: $\underline{10.1016 / j . t o u r m a n .2013 .06 .013}$.

Coy, A. E., Farrell, A. K., Gilson, K. P., Davis, J. L. \& Le, B. (2013). Commitment to the environment and student support for "green" campus initiatives. Journal of Environmental Studies and Sciences, 3: 49-55. DOI: $\underline{10.1007 / s 13412-012-0100-1}$.

Davis, J. L., Green, J. D. \& Reed, A. (2009). Interdependence with the environment: Commitment, interconnectedness, and environmental behaviour. Journal of Environmental Psychology, 29, 173-180. DOI: $10.1016 /$ i.jenvp.2008.11.001.

Davis, J. L., Le, B. \& Coy, A.E. (2011). Building a model of commitment to the natural environment to predict ecological behaviour and willingness to sacrifice. Journal of Environmental Psychology, 31: 257265. DOI: 10.1016/i.jenvp.2011.01.004.

Easterling, D., Kenworthy, A. \& Nemzoff, R. (1996). The greening of advertising: a 25-year look at environmental advertising. Journal of Marketing Theory and Practice, 4(1): 20-34. DOI: $\underline{10.1080 / 10696679.1996 .11501714 .}$.

Hair, J.F., Black, C.W., Babin, J. B. \& Anderson, R.E. (2014). Multivariate Data Analysis (7th ed.). Pearson New International Edition: Harlow: Pearson Education Limited.

Han, H., Hsu, L.T. \& Sheu, C. (2010). Application of the Theory of Planned Behaviour to green hotel choice: Testing the effect of environmental friendly activities. Tourism Management, 31: 325-334. DOI: 10.1016/j.tourman.2009.03.013. 
Han, H. (2015). Travelers' pro-environmental behaviour in a green lodging context: Converging valuebelief-norm theory and the theory of planned behaviour. Tourism Management, 47: 164-177. DOI: 10.1016/j.tourman.2014.09.014.

Han, H., Lee, M.J. \& Kim, W. (2018). Antecedents of green loyalty in the cruise industry: Sustainable development and environmental management. Business Strategy and the Environment, 27: 323-335. DOI: $10.1002 /$ bse.2001.

Han, H. \& Yoon, H.J. (2015). Hotel customers' environmentally responsible behavioural intention: Impact of key constructs on decision in green consumerism. International Journal of Hospitality Management. 45: 22-33. DOI: 10.1016/j.ijhm.2014.11.004.

Han, H., Yu, J. \& Kim, W. (2019). Investigating airline customers' decision-making process for emerging environmentally-responsible electric airplanes: Influence of gender and age. Tourism Management Perspectives. 31: 85-94. DOI: 10.1016/j.tmp.2019.03.013.

Hayes, A. F. (2013). Introduction to mediation, moderation, and conditional process analysis: A regression-based approach. New York: The Guilford Press.

He, X., Hu, D., Scott, S.R., Su, L., \& Chen, X. (2018). Destination perceptions, relationship quality, and tourist environmentally responsible behaviour. Tourism Management Perspectives. 28: 93-104. DOI: $\underline{10.1016 / j . t m p .2018 .08 .001 . ~}$

Henriques, I. \& Sadorsky, P. (1999). The relationship between environmental commitment and managerial perceptions of stakeholder importance. The Academy of Management Journal, 42(1): 87-99. DOI: $\underline{10.5465 / 256876}$.

Kasim, A. (2006). The need for business environmental and social responsibility in the tourism industry. International Journal of Hospitality \& Tourism Administration. 7(1): 1-22. DOI: 10.1300/J149v07n01_01.

Kelley, H. H. \& Thibaut, J. (1978). Interpersonal relations: A theory of interdependence. New York, NY: Wiley. Kline, R. B. (2011). Principles and practice of structural equation modeling (3rd ed.). New York: The Guilford Press.

KTB (Republic of Turkey Ministry of Culture and Tourism). (2020). Yatırım ve işletmeler genel müdürlüğü, turizm işletme belgeli tesisler. https://yigm.ktb.gov.tr/TR-9579/turizm-tesisleri.html (Access Date: 18.08.2020).

Lee, H.T. (2011). How recreation involvement, place attachment and conservation commitment affect environmentally responsible behaviour. Journal of Sustainable Tourism. 19(7): 895-915. DOI: $\underline{10.1080 / 09669582.2011 .570345}$.

Lee, T.H. \& Jan. F.H. (2015). The effects of recreation experience, environmental attitude, and biospheric value on the environmentally responsible behaviour of nature-based tourists. Environmental Management. 56: 193-208. DOI: $\underline{10.1007 / \mathrm{s} 00267-015-0488-\mathrm{y}}$. 
Mercado, H.U. \& Walker, M. (2012). The value of environmental social responsibility to facility managers: revealing the perceptions and motives for adopting ESR. Journal of Business Ethics. 110: 269284. DOI: $10.1007 / \mathrm{s} 10551-011-1153-\mathrm{x}$.

Molina-Azoin, J. F., Claver-Cortes, E., Pereira-Moliner, J. \& Tari, J. J. (2009). Environmental practices and firm performance: an empirical analysis in the Spanish hotel industry. Journal of Cleaner Production, 17: 516-524. DOI: 10.1016/j.jclepro.2008.09.001.

Perez-Lopez, D., Moreno-Romero, A. \& Barkemeyer, R. (2015). Exploring the relationship between sustainability reporting and sustainability management practices. Business Strategy and the Environment, 24(8): 720-734. DOI: $\underline{10.1002 / \text { bse.1841. }}$.

Rahman, I. \& Reynolds, D. (2016). Predicting green hotel behavioural intentions using a theory ofenvironmental commitment and sacrifice for the environment. International Journal of Hospitality Management, 52: 107-116. DOI: 10.1016/j.ijhm.2015.09.007.

Razaa, S.A., Sharif, A., Wongb, W.K \& Karim, M.Z.A. (2017). Tourism development and environmental degradation in the United States: evidence from wavelet-based analysis. Current Issues in Tourism. 20(16): 1768-1790. DOI: $\underline{10.1080 / 13683500.2016 .1192587}$.

Rusbult, C. E. (1980). Commitment and satisfaction in romantic associations: A test of the investment model. Journal of Experimental Social Psychology, 16: 172-186. DOI: 10.1016/0022-1031(80)90007-4.

Sakellari, M. \& Skanavis, C. (2013) Environmental Behaviour and Gender: An Emerging Area of Concern for Environmental Education Research. Applied Environmental Education \& Communication, 12(2): 77-87, DOI: 10.1080/1533015X.2013.820633.

Su, L., \& Swanson, S. R. (2017). The effect of destination social responsibility on tourist environmentally responsible behaviour: Compared analysis of first-time and repeat tourists. Tourism Management. 60: 308-321: DOI: 10.1016/j.tourman.2016.12.011.

Uzzell, D.L., (2000). The psycho-spatial dimension of global environmental problems. Journal of Environmental Psychology. 20, 307-318. DOI: 10.1006/jevp.2000.0175.

WTTC (World Travel and Tourism Council). (2014). Gender Equality and Youth Employment in Travel and Tourism, 1-4. URL: http://www.wttc.org/focus/research foraction/policy-research/genderequality-and-youth-employment-intravel-tourism/. (Access Date: 18.08.2020).

Xiao, C. \& Hong, D. (2018). Gender Differences in Environmental Behaviours Among the Chinese Public: Model of Mediation and Moderation. Environment and Behaviour, 50(9): 975-996. DOI: 10.1177/0013916517723126. 